\title{
Determinants of Self-Esteem, Educational Performance and Career Prospects among Secondary School Students in Navakholo Constituency, Kakamega, Kenya
}

\author{
Joyce Wangia $^{1 *} \quad$ Fuchaka Waswa $^{2} \quad$ Judith Waudo $^{3}$ \\ 1. Kenyatta University, School of Humanities and Social Sciences. P. O Box 43844-00100, Nairobi, Kenya. \\ 2. Fuchaka Waswa, Kenyatta University, School of Agriculture and Enterprise Development \\ P. O. Box 43844-00100, Nairobi, Kenya. \\ 3. Judith Waudo, Kenyatta University, School of Applied Human Sciences \\ P.O. Box 43844-00100, Nairobi, Kenya.
}

\begin{abstract}
In the quest to identify challenges to students' educational performance, cross-sectional study was carried out on 350 randomly selected students of St. Kizito and Sivilie secondary schools in Navakholo Constituency. A social survey design using closed and open-ended questionnaires was used to gather data, which was analysed using descriptive statistics. Results showed that students' self-esteem is mainly negatively influenced by demeaning comments from both class teachers and parents. These negative pronouncements eventually lead to poor schooling outcomes and difficulties in making career choices. In particular, students appeared to avoid pursuing competitive courses and careers like engineering, medicine and law. Further, they indicated having had little information regarding career choices during their school years. This study recommends that evaluation of teachers and parents/guardians by students should be encouraged albeit confidentially so that appropriate counselling could be extended to these inter-related tripartite stakeholders in pursuit of better learning environment, educational outcomes and ultimately career choices.
\end{abstract}

Keywords: Self Esteem, Learning Outcomes, Career choices, Counselling

We confirm that there is no conflict of interest. This research was self-sponsored.

DOI: $10.7176 / \mathrm{JEP} / 10-14-06$

Publication date:May $31^{\text {st }} 2019$

\section{Introduction and Background}

Self-esteem is defined in terms of the presence of a continued sense of personal worth or worthiness (Rosenberg, 1965). Career development refers to the life long process of developing work values, vocational identity and exploring different career opportunities and work (Dhillon and Kaur, 2005). Career choices are a very important component of an individual's life and for some, making this crucial decision is a hard task to achieve. In making career related decisions, a person has to accept his/her capabilities, wellbeing, talent, and values to form a significant frame for life (Walsh and Osipow, 1988). According to Patton, Bartum and Creed (2004), students who score high in self esteem are better equipped to manage developing career interests and making career related decisions. Self esteem has been found to be positively correlated to career maturity, work commitment, work values, career certainty, career decision making and self-efficacy (Creed and Patton, 2003). Self- esteem is instrumental in academic performance and career choices.

Choosing a career is an important decision that impacts on an individual's entire life and yet secondary school students in Kenya do not have access to information to enable them make this decision. There are many factors influencing career choices: these include, parental and peer influence; societal and environmental factors; professional and personal self-esteem. However, to be successful in career exploration requires that an individual seeks out various professionals such as career counsellors to aid in the process. Navin (2009) suggested that exploring career options before committing to a career increases future career success and satisfaction. Psychologists on the other hand, do believe that the career a person chooses is an expression of the personality style of that individual including one's self-esteem. There is paucity of information on self- esteem and career choices among secondary school students in Kenya and thus, the purpose of this study. This study therefore aimed at determining the self-esteem of secondary school students, and factors influencing self-esteem and career choices among them.

\section{Methodology}

A cross-sectional study took place in two mixed day and boarding secondary schools in Navakholo District, Kakamega County, in the Western part of Kenya. The two randomly selected and homogenous schools are located within rural farming communities whose livelihood is subsistence farming. A questionnaire survey consisting of both closed and open ended questions was used to collect data from 350 students. The respondents were restricted to forms 3 and 4 classes. The respondents were taken through the questionnaire in order to clarify 
all issues there-in. Data was entered in the computer, cleaned, coded and analysed for descriptive, inferential and regression analysis for general trends using SPSS version 22.0.

\section{Results and Discussion}

\subsection{Students Demographic Characteristics}

The students' social demographic information included: age, gender, parents marital status, education and income as reported in the tables $1-5$. Majority (34\%) of students from the two schools were aged 17 years old while $25 \%$ and $18 \%$ were 18 and 19 years old respectively ( Table 1). The age range was not significant and hence not a contributor of isolation and introvert tendencies.

Table 1: Students' Distribution by Age (\%)

\begin{tabular}{|l|l|l|l|l|l|l|l|l|l|l|}
\hline Age (Years) & $\mathbf{1 4}$ & $\mathbf{1 5}$ & $\mathbf{1 6}$ & $\mathbf{1 7}$ & $\mathbf{1 8}$ & $\mathbf{1 9}$ & $\mathbf{2 0}$ & $\mathbf{2 6}$ & $\mathbf{3 2}$ & Total \\
\hline Sivilie & 0.0 & 3.0 & 9.0 & 37.4 & 25.3 & 18.2 & 6.1 & 0.0 & 1.0 & 100 \\
\hline St. Kizito & 7.7 & 11.0 & 26.4 & 31.9 & 13.2 & 6.6 & 2.2 & 1.0 & 0.0 & 100 \\
\hline
\end{tabular}

Although the two schools are mixed schools, they are still dominated by boys (Table 2). This trend is common among rural schools since girls tend to drop out of school in secondary schools due to early marriages, lack of fees or early pregnancies.

Table 2: Students' Distribution by Gender (\%)

\begin{tabular}{|l|l|l|l|}
\hline Gender & Male & Female & Male to Female ratio \\
\hline Sivilie & 72.7 & 27.3 & 2.66 \\
\hline St. Kizito & 57.8 & 42.2 & 1.37 \\
\hline
\end{tabular}

St. Kizito recorded a fairly high rate of divorced and single parents (Table 3). This is a predictor of an emerging trend which previously was rare in these communities. Its negative impact on self-esteem and overall child development is widely acknowledged in human social systems. Majority of the parents (49.5\%) had secondary level education as their highest level of schooling (Table 4). The level of education is generally acknowledged to be positively correlated with aspirations and income opportunities in life. As it will be shown later in this paper, the low propensity to invest in children's education can be linked to low education levels of parents, among other factors. This finding is likely to have a negative impact on parents' self esteem and subsequently their children's self esteem.

Table 3. Marital Status of Parents

\begin{tabular}{|l|l|l|l|l|}
\hline Marital Status & Married & Widowed & Divorced & Single \\
\hline Sivilie & 87.0 & 4.0 & 2.0 & 7.0 \\
\hline St. Kizito & 73.9 & 2.2 & 13.0 & 10.9 \\
\hline
\end{tabular}

Table 4. Educational Level of Parents

\begin{tabular}{|l|l|l|l|l|l|l|l|l|l|l|}
\hline & \multicolumn{2}{l}{ University } & \multicolumn{2}{l|}{ Tertiary } & \multicolumn{2}{l|}{ Secondary } & \multicolumn{2}{l|}{ Primary } & None \\
\hline & $\mathrm{F}$ & $\mathrm{M}$ & $\mathrm{F}$ & $\mathrm{M}$ & $\mathrm{F}$ & $\mathrm{M}$ & $\mathrm{F}$ & $\mathrm{M}$ & $\mathrm{F}$ & $\mathrm{M}$ \\
\hline Sivilie & 9 & 4 & 13 & 9 & 47 & 44 & 29 & 40 & 2 & 3 \\
\hline St. Kizito & 15.2 & 13 & 9.8 & 8.7 & 50 & 57.6 & 20.7 & 16.3 & 4.3 & 4.3 \\
\hline
\end{tabular}

\section{Where: $\mathbf{F}=$ Fathers; $M=$ Mothers}

Being a rural agriculture-dependent area, majority of the parents $(39.4 \%)$ were subsistence farmers (Table 5). This would have a bearing on the self-esteem of students when it comes to difficulties in paying schools due to overall high financial poverty within households.

Table 5: Parents' Sources of Income

\begin{tabular}{|c|l|l|l|l|l|}
\hline \multirow{2}{*}{ Sources of Income } & Fathers & \multicolumn{2}{l|}{ Mothers } \\
\cline { 3 - 6 } & Sivilie & St. Kizito & Sivilie & St. Kizito \\
\hline 1. & Formal and self employed & 4.0 & 0.0 & 1.0 & 0.0 \\
\hline 2. & Formal Employment and farming & 3.0 & 0.0 & 2.0 & 1.1 \\
\hline 3. Self-employed and farming & 26.0 & 4.5 & 15.0 & 3.3 \\
\hline 4. & Farming and small trade & 9.0 & 5.6 & 13.0 & 7.6 \\
\hline 5. Subsistence Farming & 35.0 & 47.2 & 33.0 & 42.4 \\
\hline 6. & Small trade & 2.0 & 7.9 & 15.0 & 19.6 \\
\hline 7. & Self Employed & 9.0 & 21.3 & 11.0 & 18.5 \\
\hline 8. & Formal Employment & 9.0 & 13.5 & 5.0 & 6.5 \\
\hline
\end{tabular}

\subsection{Students' Self-Esteem}

\subsubsection{What Students do not like about themselves}

Majority of students (45\%) in Sivilie singled-out poor academic performance as an aspect that made them not to like themselves. For St Kizito the score was 39.1\% (Table 6). Such a self-destructive feeling is worsened by the negative comments made by both teachers and parents. Together with bad grooming and the thought of having 
poor physical appearance, the low self-esteem among students in the two schools was bound to fall. Making students feel that they are unique and beautiful in their own right is certain to nullify such low self-esteem tendencies. The problem is lack of respected persons who can do this consistently.

Table 6: Aspects Student do not like about themselves

\begin{tabular}{|c|c|c|}
\hline Item & Sivilie & St. Kizito \\
\hline 1. My gender & 1.0 & 1.1 \\
\hline 2. Poor academic performance & 45.0 & 39.1 \\
\hline 3. Indiscipline tendencies & 39.0 & 42.4 \\
\hline 4. $\quad$ Bad grooming & 9.0 & 5.4 \\
\hline 5. Physical appearance & 5.0 & 4.3 \\
\hline 6. All things about me & -- & 7.6 \\
\hline
\end{tabular}

Self-esteem fluctuates during one's lifespan. It is high in childhood, drops in adolescence, rises in adulthood and declines during old age. Self-esteem in childhood is high but as children make transition from pre-school to primary school, they experience more negative feedback from teachers, parents and peers, which make their selfevaluation become negative. As they transit to adolescence, self-esteem drops because of maturation cycles associated with puberty, cognitive changes and socio-contextual changes associated with transition from primary to secondary school (Robins et al, 2002). During adolescence, girls' self-esteem drops resulting in gender differences in ages 13-17 years. When children enter school their self-esteem is already formed through the influence of parents. It is therefore a combination of school factors, family and innate intelligence that appears to be essential ingredients in increasing student's self-esteem during the academic years (Abdullar, 2000). Generally as students get older their self-esteem diminishes. Accordingly self-esteem is created by how one is treated by others through our experiences and activities. There are numerous causes of low esteem. These include: poor health, being bullied, lack of support from family, friends and teachers, dysfunctional family and lack of achievement of work. This study investigated factors contributing to low self esteem among secondary school students.

\subsection{2: Factors Affecting Students' Self-Esteem}

Majority of students $(23 \%)$ see their parents as providers of basic needs and care. Fees and basic needs stand out as critical self-esteem killers if not provided by parents. When parent fail in this responsibility, the children feel unloved, neglected and unwanted. For girls some basic needs like sanitary pads can be a real challenge. When parents fail in this responsibility the students develop the feeling of being unwanted and a bother, which results in diminished self-esteem and by extension performance. At $46 \%$ score, the role of teachers as providers of guidance and counselling services, particularly on academic and career development cannot be over-emphasised. In terms of showing love, support, encouragement and mutual respect, siblings at home ranked highest at $23 \%$ response (Table 7). Their contribution to their peer's self-esteem cannot be overemphasised.

Table 7: Factors that have influenced students' self-esteem in St. Kizito (2016) (n=94

\begin{tabular}{|l|c|c|c|}
\hline & \multicolumn{3}{|c|}{ No of respondents (\%) } \\
\hline Influence factor & Parent & Teacher & Siblings \& peers \\
\hline Provision of basic needs and care & 23 & - & - \\
\hline Guidance, counselling and affirmation & 21 & 46 & 3 \\
\hline Taking personal interest in student & 4 & 5 & - \\
\hline Encouragement, love, support and motivation & 15 & 3 & 23 \\
\hline Negative influence and pronouncements & 1 & 2 & 10 \\
\hline Role Modelling & - & 1 & 3 \\
\hline Negative influence and pronouncements & - & - & 1 \\
\hline Involvement, inclusion and mutual respect & 1 & 1 & - \\
\hline Divorce and family feuds & 5 & - & \\
\hline
\end{tabular}

Regular positive affirmation of the child by the parent raises their self-esteem, while scolding, threats, negative pronouncements kill the spirit. The impact of divorce and family feuds on the child's self-esteem cannot be overemphasised. The self-esteem of students whose parents are known to be bad role models in the community is naturally lowered. Students value guidance and counselling from their teachers. How it is done and what it entails is key to the expected success. Showing personal interest in the student can be very inspiring. Public display of biases against some students is a killer of self-esteem. Punishing poor performance instead of advising, including meting punishment for mistakes students cannot identify with destroys self-esteem. Statements by significant others that did kill the morale of students are listed in tables $8 \mathrm{a}$ and $8 \mathrm{~b}$. 
Table 8a: Parents and Teachers pronouncements that crush students' self-esteem at Sivilie, 2018

From Parents

1. You are a failure and useless

2. You will not go past university

3. If children were bought, I could buy one and take to school

4. You are good for nothing

5. You are not studying for me

6. I will not waste time on you

7. I left a baby and picked a placenta

8. You are not my child

9. Who gave birth to such a stupid fellow?

10. You look like a "street" child

11. You are always confused like your mother

12. You are stupid

13. You are wasting my property and resources

14. Do not think you are so special

15. If you do not perform you will not be my son

\section{From Teachers}

1. You are a failure and useless

2. Teaching you does not help

3. Some people are born fools

4. You are wasting your parent's fees

5. You have empty heads

6. You will not pass

7. You are an empty "debe" (Metallic Container)

8. You are ugly

9. Your mind is blocked. You will never follow instructions

10. You are lazy

11. I will not associate with you because you keep failing my subject

Table 8b: Parents and Teachers Pronouncements that crush students' self-esteem at St. Kizito, 2018

From Parents

1. Go and get married

2. You are silly like a cow

3. You are unable to succeed

4. A stupid person cannot accept correction

5. You are useless

6. You fail again, I do not pay fees again

7. You will never have a good future

8. You will never be blessed

9. You undisciplined mongoloid

10. You have wasted fees. I have no time for you

11. You silly. How did you come in this family?

12. You are stupid as your father

13. You will be a herdsman in the village

Students reported that such statements should not be thrown at them while they are trying their best in school and home. Olaosebikan et al (2014) reported that parental influence has a negative effect on adolescents career choices as only $40.36 \%$ of his respondents relied on parents for career exploration. His study also reported that secondary school students made independent choices regarding career choices. Olamide et al (2013) reported that schools lack career counsellors which made students rely on parents for career choices. Students do listen to people around them while choosing careers. Students at times aim at choosing prestigious careers while in reality they may not make it to practicing that career for one reason or the other. Poor academic performance, poor subject combinations and insufficient information regarding different jobs in the market place make secondary students make poor career choices.

\subsubsection{Rank of Factors Influencing Students' Self-Perception}

At mean scores of $3.88 \%$ and $3.78 \%$, the self-esteem of students in both schools was not significantly different. Parents and teachers have the greatest influence on students' self-perception while students' peers have the least influence on their self-perception (Table 9). However, it is important to note the significant standard deviation of about 1.14 on the peers' influence, which implies that the sampled students differed greatly on the influence of their peers on their self-perception. Nevertheless, a standard deviation of 0.86 and 0.99 indicates that most of the sampled students tend to agree more on the influence of parents on their self-perception.

Table 9. Rank of Factors Influencing Sivilie Students' Self-Perception

\begin{tabular}{|c|c|c|c|c|c|c|}
\hline \multirow[t]{2}{*}{ Source of Influence } & \multirow[t]{2}{*}{ Range } & \multicolumn{2}{|c|}{ Mean } & \multicolumn{2}{|c|}{ Std. Dev } & \multirow[t]{2}{*}{ Rank } \\
\hline & & Sivilie & St. Kizito & Sivilie & St. Kizito & \\
\hline Parents & $1.00-4.00$ & 1.76 & 1.62 & 0.996 & 0.86 & 1 \\
\hline Teachers & $1.00-4.00$ & 2.19 & 2.20 & 1.002 & 0.97 & 2 \\
\hline Siblings & $1.00-4.00$ & 2.71 & 2.76 & 1.026 & 0.98 & 3 \\
\hline Peers & $1.00-4.00$ & 2.86 & 2.81 & 1.054 & 1.14 & 4 \\
\hline
\end{tabular}




\subsubsection{Students' Role Models}

Whereas role models could be people from a wide range of influence, teachers and parents stood out as critical role models to their students and children respectively in Sivilie and St. Kizito schools (Table 10). Negative evaluation from such authority figures tends to make a person feel stupid, dumb and lose confidence in oneself. Some repeated criticism does damage self-worth and self-confidence. It could be worse when a child senses nonacceptance in his or her own family. Studies have reported the greater the non-involvement of the parents with the child, the lower, the self-esteem. According to Thompson (1995) self-esteem has been associated with important appeals of human behaviour such as general adjustments, anxiety, acceptance of other people and child rearing practices. Generally a person with high self-esteem has the right attitudes to succeed while a person with low self-esteem feeds negative thinking and does not take criticism positively.

\section{Table 10: Students' Role Models}

\begin{tabular}{|c|l|l|}
\hline Category & Sivilie & St. Kizito \\
\hline 1. School Principal & 13.7 & 6.4 \\
2. Teachers & 16.8 & 19.1 \\
3. Fellow students & -- & 10.6 \\
4. Siblings & 1.1 & -- \\
5. Parents & 4.2 & 14.9 \\
6. Father & 3.2 & 4.3 \\
7. Mother & 2.1 & 10.6 \\
8. The President of Kenya & 2.1 & -- \\
9. Barak Obama & 5.3 & 2.1 \\
10. Donald Trump & 1.1 & -- \\
11. Dr. Matiangi (Cabinet Secretary) & 2.1 & -- \\
12. Others & 43.2 & 31.9 \\
\hline
\end{tabular}

According to Reese (2011) low self-esteem can be caused by pressure from parents to excel in school or a particular sport. According to Scot and Murray (1996) both academically and interpersonal, student's self-esteem is affected by evaluations not only from school personnel but also from peers and family members. Because of the multiple academic and social roles that students assume, they must constantly evaluate their knowledge and skills and compare them to others.

Self-esteem is the foundation of one's character and career performance. Self-esteem fluctuates during the life cycle as it declines as one ages. A combination of family, school and innate factors do affect self-esteem (Abdullar, 2000). A relation between self-esteem and academic performance is well stabled (Akinleke, 2012). According to this author, students with high self- esteem do perform better than those with low self-esteem. High esteem leads to enriched initiative and pleasant learning. Twinomogisha (2008) reported that boys generally scored high on self- esteem compared to girls while other researchers found no significant differences in the selfesteem scores of boys and girls. Family, school and innate factors do influence self-esteem among students. In general self-esteem of adolescents is more affected by parental behaviour (Webster, 2001). Studies have established a relation between self-esteem and career choices in that those students with high self-esteem tend to choose careers that are science and technology based compared with students with low self-esteem that pick art and creative based careers such as music and creative arts.

\subsection{Self Esteem and Academic Performance}

Majority (48.5\%) of sampled students from Sivilie Secondary school are fond of science subjects compared to humanities and languages which were preferred by $36.2 \%$ and $15.5 \%$ of the sampled students respectively (Table 11). 
Table 11: Comparison of Subjects in Terms of Popularity (\%)

\begin{tabular}{|l|l|l|l|l|}
\hline Category & Subject & Sivilie & St. Kizito & Mean Score \\
\hline \multirow{5}{*}{ Sciences } & Biology & 17.5 & 9.4 & 13.7 \\
\cline { 2 - 5 } & Chemistry & 5.2 & 11.8 & 8.2 \\
\cline { 2 - 5 } & Physics & 1.0 & 4.7 & 2.7 \\
\cline { 2 - 5 } & Mathematics & 12.4 & 10.6 & 11.5 \\
\cline { 2 - 5 } & Agriculture & 12.4 & 4.7 & 8.8 \\
\cline { 2 - 5 } Total & Computer Studies & 0.0 & 5.9 & 2.7 \\
\hline \multirow{5}{*}{ Humanities } & & $\mathbf{4 8 . 5}$ & $\mathbf{4 7 . 1}$ & \\
& History & 12.4 & 15.3 & 13.7 \\
\cline { 2 - 5 } & CRE* & 3.1 & 12.9 & 7.7 \\
\cline { 2 - 5 } & CRE/History & 2.1 & 4.7 & 3.3 \\
\cline { 2 - 5 } & Geography & 3.1 & 1.2 & 2.2 \\
\cline { 2 - 5 } & Business Studies & 15.5 & 4.7 & 10.4 \\
\hline \multirow{5}{*}{ Lotal } & & $\mathbf{3 6 . 2}$ & $\mathbf{3 8 . 8}$ & \\
\hline Total & English & 6.2 & 7.1 & 6.6 \\
\cline { 2 - 5 } & Swahili & 7.2 & 4.7 & 1.1 \\
\cline { 2 - 5 } & English/Swahili & 2.1 & 0.0 & 0.5 \\
\cline { 2 - 5 } & French & 0.0 & 1.2 & $\mathbf{1}$ \\
\hline
\end{tabular}

*CRE $=$ Christian Religious Education.

According to Otta et al (2012) those students with high self-esteem turned to choosing scientific and professional courses with those with low self-esteem turning to outdoor, mechanical and artistic type of careers. Eremie (2015) indicated that students who have low self-esteem have high preference for occupations like farming, while those with high self-esteem prefer professionally oriented occupations. Students with high selfesteem were found to aspire for white collar jobs. On the other hand, students with low self-concept were found to aspire for artistic and realistic occupation (Eremie, 2017).

Self-esteem level of students with humanities as their best subjects was slightly higher (3.98) than those who mentioned science subjects as their best subjects (3.83) (Table 12). Students who indicated languages as their best subjects had the lowest (3.56) level of self-esteem

Table 12: Best Subject Verses Self-Esteem

\begin{tabular}{|l|l|l|l|}
\hline Subject Groups & Best Subjects & Mean Self-esteem Level & Mean \\
\hline \multirow{5}{*}{ Sciences } & Biology & 3.64 & $\mathbf{2 2 . 9 6 / 6 = 3 . 8 3}$ \\
\cline { 2 - 3 } & Chemistry & 4.13 & \\
\cline { 2 - 3 } & Physics & 4.00 & \\
\cline { 2 - 3 } & Mathematics & 3.86 & \multirow{4}{*}{$\mathbf{1 9 . 9 / 5}=\mathbf{3 . 9 8}$} \\
\cline { 2 - 3 } & Agriculture & 4.13 & \\
\cline { 2 - 3 } & Computer Studies & 3.20 & \\
\hline \multirow{5}{*}{ Lumanities } & History & 3.64 & $\mathbf{1 4 . 2 2} / \mathbf{4}=\mathbf{3 . 5 6}$ \\
\cline { 2 - 3 } & CRE & 4.14 & \\
\cline { 2 - 3 } & CRE/History & 4.17 & \\
\cline { 2 - 3 } & Geography & 4.00 & \\
\cline { 2 - 3 } & Business Studies & 3.95 & \\
\hline & English & 3.58 & \\
\cline { 2 - 3 } & Swahili & 3.64 & \\
\cline { 2 - 3 } & English/Swahili & 4.00 & \\
\cline { 2 - 3 } & French & 3.00 & \\
\hline
\end{tabular}

However, the difference between the students' level of self-esteem was not very big across the subjects. The relationship between self-esteem and academic achievement is one that is regarded by many educators as a wellestablished fact (Akinleke, 2012). Academic achievement of students is influenced by many factors such as student related, teacher related and school related (Arshael et al (2015). Akinleke, (2012) reported that high selfesteem is an important factor and strengthen the prediction of academic achievement among students. High selfesteem leads to enriched initiatives and pleasant feeling to learning. According to Abdullar (2000), low selfesteem in students creates a lack of interest to strive for high academic performance. He further asserts that there were no significant differences in self-esteem and academic achievement of boys compared to girls. Twinomogisha (2008) on the other hand, reported that boys scored significantly high on self-esteem and academic achievement compared to girls. 
Vishalakshi et al (2012) reported positive association between self-esteem and academic performance. Hisken (2011) reported a positive relationship between self-esteem and student reading ability. Reading levels increased among students with high self- esteem and this lead to good academic achievement. In other words, student's level of self-esteem was positively impacted if they were successful in reading and other academics. On the other hand, Thompson (1998) reported no significant relationship between academic achievement and self-esteem. He also found no significant differences between self-esteem and academic performance among African American males and females. The study showed that students with lower grades did not necessarily have low self-esteem contrary to the popular belief that self-esteem is related to high academic achievement.

\subsection{Career Choices}

In terms of career choices, students' preferred the traditionally overrated careers such as being a doctor or a lawyer or an engineer (Table 13). However, judging by their educational environment and the 2018 Kenya Certificate of Secondary School Examination performance, most would not actualise these careers.

Table 13. Students' Career Aspirations

\begin{tabular}{|c|l|l|}
\hline Career & Sivilie & St. Kizito \\
\hline 1. Entrepreneur & 1.0 & -- \\
\hline 2. Politician & 1.0 & -- \\
\hline 3. Banker & 3.0 & -- \\
\hline 4. ICT Expert & 2.0 & 3.3 \\
\hline 5. Nurse & 3.0 & 4.4 \\
\hline 6. Doctor & 24.0 & 24.4 \\
\hline 7. Pilot & 2.0 & 6.7 \\
\hline 8. Military & 3.0 & 5.6 \\
\hline 9. Teacher & 5.0 & 7.8 \\
\hline 10. Accountant & 7.0 & 6.7 \\
\hline 11. University Lecturer & 15.0 & 3.3 \\
\hline 12. Journalist & 7.0 & 4.4 \\
\hline 13. Legal profession & 17.0 & 16.7 \\
\hline 14. Engineer & 10.0 & 10.0 \\
\hline 15. Architect & -- & 1.1 \\
\hline 16. Economist & -- & 1.1 \\
\hline 17. Pastor & -- & 1.1 \\
\hline In terms of the age at which & - & \\
\hline
\end{tabular}

In terms of the age at which students start making career choices, results showed that most students have an idea of what they want to be at a very early age of 5-15 years (Table 14). But whether they eventually become is doubtful. Perhaps such earlier aspirations should be the basis of mentoring as they go through their schooling. Constantly being reminded of such aspirations and how to get there should be part of the mentoring process.

Table 14: Age in Life Career Decisions were Made

\begin{tabular}{|c|c|c|}
\hline Age career decision & Sivilie & St. Kizito \\
\hline 1. $5-12$ & 46 & 38.3 \\
\hline 2. $13-15$ & 23 & 31.4 \\
\hline 3. $16-20$ & 9 & 22.1 \\
\hline 4. $>20$ & 18 & 5.8 \\
\hline
\end{tabular}

Further students from St. Kizito seemed to be more informed about their dream careers compared to their peers from Sivilie secondary school (Table 15). It may be the school has more intentional approach to exposing students to potential careers through internal mechanisms or through external motivational speakers. That there is a significant relationship between self-esteem and career choices has also been corroborated by Olaosebikan et al (2014) who found that adolescents with high self esteem are more confident in choosing careers. Javed et al (2016) reported that career decision making were negatively correlated with self esteem which means that those students with higher career decision making difficulties had lower self esteem. According to Javed et al, 2016 in Pakistan it was found that students in government academic institutions had difficulties in choosing careers as opposed to their counterparts in private institutions. It is also easier for those students with high self- esteem to make career choices. A study carried out among students in Australian high schools by Creed, et al. (2004) revealed that the stability of an individual's self-esteem and optimism predicted ones career planning and career exploration 
Table 15: Career awareness

\begin{tabular}{|c|l|l|}
\hline Career Awareness & YES & NO \\
\hline 1. Sivilie & 80.0 & 20.0 \\
\hline 2. St. Kizito & 91.0 & 9.0 \\
\hline Interaction with Professionals & YES & NO \\
\hline 1. Sivilie & 61.0 & 39.0 \\
\hline 2. St. Kizito & 75.9 & 24.1 \\
\hline Need for School assistance in career choices & YES & NO \\
\hline 1. Sivilie & 93.9 & 6.1 \\
\hline 2. St. Kizito & 97.8 & 2.2 \\
\hline
\end{tabular}

Eremie (2017) on the other hand reported that there is no significant difference between self-esteem and occupational aspiration of male and female students. However, Javed et al (2016) and Otta et al (2012) reported that there were gender differences. They reported that male students were more confident about future careers than female students. However, according to Munanu (2010) who studied relationships between self-esteem and career aspirations among students in Nairobi County found that girls exhibited higher self-esteem than boys. This is a shift from most researches that report males having higher self- esteem than females. This is attributed to the fact that in Kenya, attention has been on the girl child welfare including education while the boy child is neglected thereby influencing their self-esteem. These findings are also supported by the fact that the study was carried out in an urban area where there has been a lot of female emancipation backgrounds than would be in the rural set ups where cultures or traditions may exhibit conservative tendencies. This is also supported by Migunde et al, (2016 ) who carried out a study of self-esteem among students in Kisumu town which showed that female students reported higher self-esteem than did male students. Moreover, there is a tendency for parents in rural communities to prefer spending resources on educating the male child rather than the female which could negatively impact on the self esteem and career choice of the female child.

\section{Conclusions and Recommendations}

Students in both St Kizito and Sivile secondary schools have low self-esteem and rely mostly on their parents for career choices, their low educational level notwithstanding. Self-esteem was mainly influenced through the satisfaction obtained when their basic needs are met, provision of guidance and counselling services, and care and support from family, teachers and peers. Although the students make career decisions between the ages 5 and 15 years, what they end up doing is influenced by their academic performance, which is unfortunately undermined by negative pronouncements from both parents and teachers. This is exacerbated by the students having little or no interaction with professionals regarding career choices.

This study recommends that parents be encouraged to meet the basic needs of their children while in school as this is one of the major contributors of low self -esteem. Schools need to create career awareness activities immediately form one students join their school. Since adolescent years are critical years for instilling good selfimage and positive self-esteem, parents and teachers should desist from making negative statement that lower students' self esteem and negatively impact their performance and ultimate career choices. It is essential that teachers and parents have a sound understanding of both self-concept and self-esteem and how these function in order to assist students. As such teachers who exhibit high self-esteem may serve as important role models and positively influence students' career choices. Parental acceptance, approval and support are significantly important in the development of self-esteem and consequently career choices. Further, routine re-tooling of all teachers and educators in self-esteem, emotional intelligence and professional ethics is essential and a mandate school management boards may not ignore.

\section{References}

Abdullah O.E (2000) Relationship among Achievement, Motivation and Self-esteem, locus of Control \& Academic Performance of Nigerians. The Nigerian Journal of Guidance and Counseling vol.7(1) pp. 130141

Akinleke, O.W. (2012) An investigation of the Relationship between Test Anxiety, Self Esteem and Academic Performance among Polytechnic Students in Nigeria. International Journal of Computer Application 51(1) pp.47-50.

Arshad M, Zaidi M and Mahmoud, K. (2015) Self Esteem and Academic Performance among Universal Students. Journal of Education and Practice vol. 6., pp. 156-162

Creed, P. A. and Patton, W. (2003). Difference in career attitudes and career knowledge for high school students with and without paid work experience. International Journal for Educational and Vocational Guidance, 3, $31-33$.

Creed, P.A, Bartrum, D. A., and Wendy, P. (2004). Gender Differences for Optimism, Self-esteem, Expectations 
and Goals in Predicting Career Planning and Exploration in Adolescents. International Journal for Educational and vocational guidance.www.works.bepress.com

Dhillon, U, and Kaur, R. (2005). Career maturity of school children. Journal of the Indian Academy of Applied Psychology, 31, 71-76.

Eremie M.D. (2015). Self Esteem Among Private and Public Secondary School Students in Rivers State: Implication for Counselling. Arabian Journal of Business and Management Review, 4(11)

Eremie, M. and Ikpah, G.U (2017). Self Concept and Occupational Aspiration Among Secondary School Students in Rivers State. International Journal of Innovative Psychology \& Social Development 5(2):1-4

Hisken, (2006). Correlation between Self Esteem and Students reading ability, reading level and Academic Achievement. M.Ed Thesis. University of Central Missouri.

Javed, Z and Tariq, O (2016). Career Decision, Self Efficacy and Self Esteem among Students of Private and Government Academic Institutes. Pakistan Journal of Social and Clinical Psychology. Vol. 14, no. 2 pp. $42-46$.

Migunde, Q., Othuon,L. and Mbagaya, C. (2016) Adolescents Self Esteem And Its Effect On Career Development. International Journal of Vocational and Technical Education Research Vol.2, No.2, pp.36-44

Mohamed A (2010). Relationship between Self Esteem and Academic Achievement among Pre-University Students. Journal of Applied Sciences pp. 77-80.

Munanu, S.K. (2010). Relationship among school type and Secondary school students' self Esteem, Academic achievement and career Aspirations in Nairobi County, Kenya. Doctor of Philosophy in Educational Psychology, Kenyatta University.

Navin, D,S (2009). Effects of Dating and Parental Attachment on Career Exploitation. U.S.A. University of New Hempshine.

Olamide, S.O and Olawaiye, S.O (2013). Factors Determining Choice of Career among Secondary School Students. The International Journal of Engineering and Science. Vol. 2. pp. 33-44.

Olaosebikan, O and Olusakin, M (2014) Effects of Parental Influence on Adolescent Career Choice in Badagry Local Government Area of Lagos Estate, Nigeria. Journal of Research in Education Vol. 4, pp. 44-57.

Otta, P.E and Okwuonu. N.W (2012). Self Esteem and Career Choices. Asian Journal of Social Sciences and Humanities. Vol 1, no, 4 pp. 37-42.

Remie M and Uche Ilepah (2017). Self Concept and Occupational Aspirations among Secondary School Students in River State. International Journal of Innovative Psychology and Social Development 5 (2) 1-4

Rosenberg, M. (1965) Society and the adolescent self-image. Princeton, NJ: Princeton University Press.

Thompson, L (1995). A descriptive study of relationship between Academic Achievement and Self Esteem. Digital Commons @Robert Woodruff Library, Atlanta Universal Center SN 1- 1995.

Vishalakshi, K. K and Yeshodhara K. (2012). Relationship between self-esteem and Academic Achievement of Secondary School Students. Journal of Applied Research pp83-84 vol. 1 issue: 12

Walsh, W. B and Osipow, S. H. (1988). Career decision making. Hillsdale, N.J: L. Erlbaum Associates. 